\title{
Gyors mikrobiológiai kimutató eszközök
}

A z élelmiszerekben előforduló mikrobák kimutatása hosszú múltra tekint vissza. Számos, napjainkban is használt mikrobiológiai vizsgálati módszer több mint százéves múltra tekint vissza.

Az élelmiszerek mikrobiológiai ellenőrzésének két alapvető feladata az élelmiszer-biztonsági és a technológiaihigiéniai kritériumoknak való megfelelés biztosítása. A probléma fontosságát jelzi, hogy a fejlett országokban évente a lakosság kb. 30\%-a szenved valamilyen élelmiszer-eredetű megbetegedésben.

Az élelmiszerekben lévő mikrobiológiai veszélyek az élelmiszer-eredetű megbetegedések egyik fő forrását jelentik. $\mathrm{Az}$ élelmiszerek nem tartalmazhatnak mikroorganizmusokat, azok által termelt toxinokat vagy anyagcseretermékeket olyan mennyiségben, amely elfogadhatatlan mértékű kockázatot jelent az ember egészségére.

A hagyományos, tenyésztésen alapuló kimutatási módszerek az élelmiszerekben jelenlévő élő baktériumsejtek izolálásához és számának meghatározásához specifikus, mikrobiológiai tápközegeket igényelnek. A hagyományos módszerek azonban időigényesek (mikroorganizmustól függően általában 1-4 nap), így az eredmények gyakran csak több napos inkubálást követően értékelhetők, mivel a mikroorganizmusoknak szemmel látható telepeket kell kialakítaniuk a táptalajokon. A módszertani fejlesztések ezért évtizedek óta az alternatív és gyors eljárások irányába haladnak, amelyek segítségével lehetőség nyílik a romlást okozó és patogén mikroorganizmusok gyors kimutatására, azonosítására és számuk pontos meghatározására.

Napjainkban, az élelmiszertételek gyors minősítése, az átmeneti tárolás időszükségletének csökkentése, és a HACCP (Hazard Analysis Critical Control Points - Veszélyelemzés Kritikus Szabályozási Pontok) hatékony működtetése is feltétlenül igényli a mikrobiológiai kiértékelés gyorsítását, automatizálását, lehetőség szerint költségcsökkentéssel együtt. A gyorsteszteket önellenőrzés céljából, elsősorban a polgári életben az élelmiszer-előállító üzemek részére fejlesztették ki.

\section{ATP BIOLUMINESZCENCIA MÉRÉS}

Az ATP-luminometria egy olyan gyors biokémiai módszer, amely a szentjánosbogár fénykibocsátásában is működő luciferin-luciferáz enzimrendszert alkalmazza [2]. Az eljárás lényege, hogy a vizsgált mintához luciferáz enzimet adnak, az enzim reakcióba lép az élő szervezetek (mikroorganizmusok, állati sejtek) energiatároló komponensével (az ATPvel) és világítani kezd.

$$
\begin{gathered}
\text { luciferin/luciferáz }+ \text { ATP }+\mathrm{O}_{2} \rightarrow \\
\rightarrow \text { oxiluciferin + luciferáz }+ \text { AMP + fény }(560 \mathrm{~nm})
\end{gathered}
$$

A reakcióhoz szükség van ATP-re és a luciferin-luciferáz enzim szubsztrát rendszerre. A reakció során átmenetileg oxiluciferin-luciferáz-AMP komplex (összetétel) képződik, amely gyorsan bomlik, és az oxiluciferin a felszabaduló energiát foton formájában adja le.

Összefoglalva: az enzimes reakció hatására a jelen lévő ATP fénykibocsátás mellett reagál. A folyamat során keletkező fényt egy készülék, az ún. luminométer érzékeli és méri. Minél nagyobb a fényintenzitás, annál nagyobb az ATP-tartalom és annál nagyobb a szennyeződés mértéke [5].

A módszert széles körben használják élelmiszeripari nyersanyagok (hal, hús, tej), késztermékek (italipar, tejipar), valamint víz vizsgálatára; leggyakrabban azonban a felületek higiéniai ellenőrzésére, ahol néhány perc alatt megoldható a tisztítás-fertőtlenítés hatásfokának kontrollja. Felületek vizsgálatának esetében, adott üzemi környezetben a módszer gyorsan, jó becslést ad a szennyezettség mértékére, így a valós idejű monitorozás értékes eszköze.

Az élelmiszer nyersanyagok, mint a növényi és állati szövetek ATP-ben gazdagok, amely lassabban és nem teljesen bomlik le a sejtek szétesése során. Ezért mikrobiológiai szennyezettség meghatározásakor a mikroba sejtek hatékony elválasztása, valamint a nem-mikroba sejtek eltávolítása fontos a vizsgálat elvégzése előtt. A módszert sikeresen alkalmazták friss húsok és tejek minőségének ellenőrzéséhez, starterkultúrák aktivitásának méréséhez, valamint UHT élelmiszerek sterilitásának ellenőrzéséhez. A módszer továbbfejlesztésével (antitest-alapú biolumineszcencia, fág-alapú biolumineszcens eljárás) lehetőség nyílt egyes patogének kimutatására is.

\section{Gyorstesztek használata a Magyar Honvédségben}

A Magyar Honvédség Logisztikai Központ 2018-ban a Bentley Magyarorszag Kft. által forgalmazott MicroSnap mikrobiológiai gyorsteszteket beszerzése mellett döntött (1. ábra). A mikrobiológiai gyorstesztek használata az élelmiszerek
ÖSSZEFOGLALÁS: A Magyar Honvédség Logisztikai Központ Átvételi Osztálya (továbbiakban: MH LK TI Á0) bevezette a gyors mikrobiológiai kimutató eszközök használatát. Mivel a hagyományos laboratóriumi körülmények között végzett vizsgálatok időigényesek, ezért igény mutatkozott arra, hogy a mikrobák kimutatására szolgáló mikrobiológiai módszereket jelentősen gyorsabb vizsgálati eljárásokkal váltsuk fel.

KULCSSZAVAK: biolumineszcencia, gyorsteszt, luminométer, mikrobák, összcsíra
ABSTRACT: The Department of Acceptance of the Hungarian Defense Forces Logistics Center (hereinafter: MH LK TI Á0) in many cases works with rapid microbiological detection tools. Since tests under conventional laboratory conditions are time consuming, there has been a need to replace microbiological methods for microorganism detection with significantly faster techniques.

KEY WORDS: bioluminescence, rapid test, luminometer, microorganisms, total germ

\footnotetext{
ORCID: 0000-0003-3499-5846

** Őrnagy, MH LK TI ÁO. ORCID: 0000-0002-0279-5172
} 


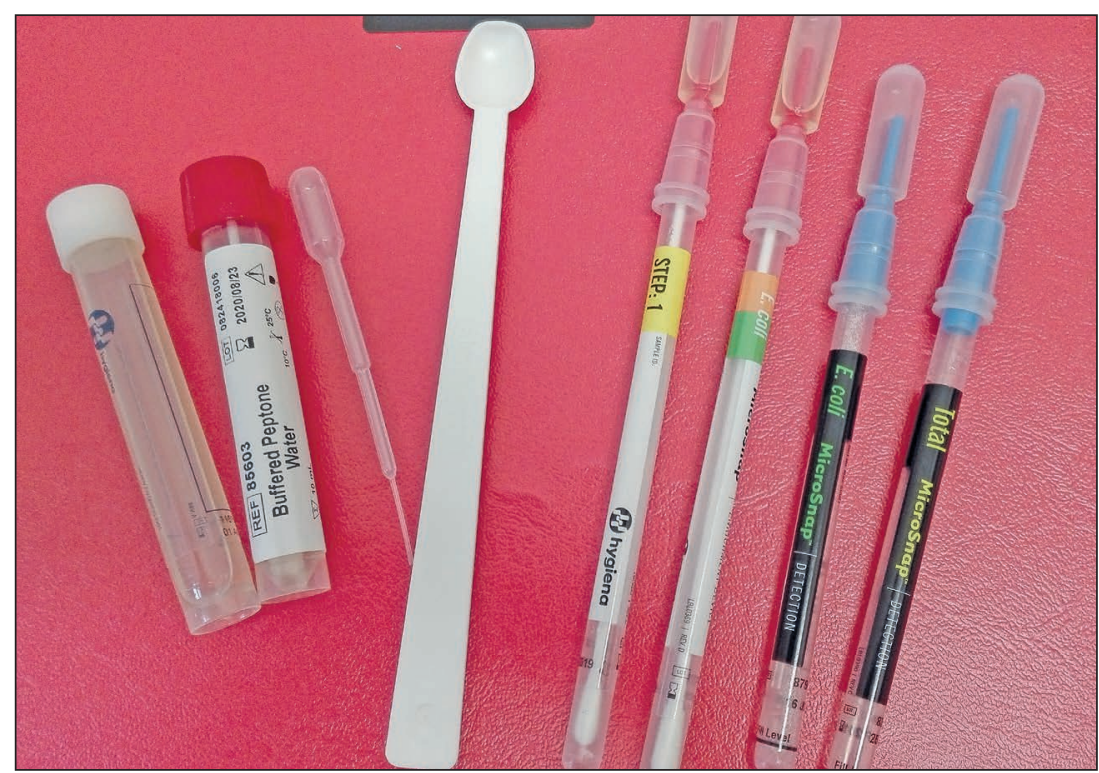

1. ábra. Mikrobiológiai gyorstesztek, vizsgálati eszközök

minőségének ellenőrzésében egy új képesség. Bevezetésük azért vált szükségessé, mert általuk az élelmiszerek minősége könnyen, kényelmesen és gyorsan megállapítható.

A gyors mikrobiológiai tesztek rövidebb időn belül (6-7 óra) adnak eredményt az élelmiszerek minőségére vonatkozóan, mint a hagyományos laboratóriumi technikákkal elvégzett vizsgálatok. Használatuk egyszerű; hordozható, olyan tesztrendszer, amely a beszállítók ellenőrzésére biztosít lehetőséget a minőségbiztosítási folyamatokban. A MH LK TI ÁO a vizsgálatok gyorsasága miatt ezt a vizsgálatot rendszeresíti az ellátási rendszerbe. A hagyományos módszerekkel történő összevethetőség miatt a Szent István Egyetem Mikrobiológiai Tanszékének munkatársai összehasonlító laborvizsgálatokat végeztek a hagyományos labor kimutatási módszerekkel. A 4/1998. (XI. 11.) EüM rendelet az élelmiszerekben előforduló mikrobiológiai szennyeződések megengedhető mértékéről és a 2073/2005 EK rendelet az élelmiszerek mikrobiológiai kritériumairól alapján kidolgozták azokat a határértékeket, amelyekkel az élelmiszer minták kiértékelhetők (1. táblázat) és elvégezték a szakállomány betanítását [6-7].

Az Átvételi Osztály a szállítói szerződésekben foglaltaknak megfelelően munkája során az élelmiszertermékek gyártóinál, illetve beszállítóinál gyártásközi ellenőrzést hajt végre és a szerződésben szereplő termékekből minőségi vizsgálatok céljára mintavételt végez. A kivett termékmintákat független akkreditált laboratóriumban bevizsgáltatja. A hosszabb laborvizsgálati eredmények kiadásának idejét lerövidíthetik a gyors mikrobiológiai tesztek alkalmazásával, ami gyanú esetén nem zárja ki a megerősítő hagyományos laborvizsgálati kiértékelést.

\section{A MEgLÉVŐ GYORSTESZTEK TÍPUSA}

\section{MICROSNAP COLIFORM ESCHERICHIA COLI (RÖVIDEN: E. COLI) BAKTÉRIUMOK KIMUTATÁSÁRA}

Az Enterobacteriaceae család képviselői széles körben elterjedtek, jelen vannak a talajban, a vízben, a növényekben és az állati, illetve az emberi bélcsatornában. Ezért jelenlétük az ilyen jellegű szennyeződésekre, különösen a fekál szennyezés jelzését tekintve, indikátor szereppel bír és számuk meghatározása az élelmiszer-mikrobiológiai laboratóriumok egyik leggyakoribb feladata [1]. Az élelmiszerekre meghatározott mikrobiológiai kritériumok egy része is erre a családra vonatkozik.

$\mathrm{Az}$ Enterobacteriaceae családba tartozó Escherichia fajok többsége az emberi és állati bélcsatornában él. Az Escherichia coli az ember vastagbelének természetes lakója, fontos szimbiótának tekinthető, azonban bizonyos szerotípusok fertőző betegségeket okoznak.

A MicroSnap termékek egy biolumineszcencián (fénykibocsátással járó kémiai reakció) alapuló gyors eljárás összes baktériumszám kimutatására és megszámlálására alkalmasak. Ezek a tesztek kevesebb,

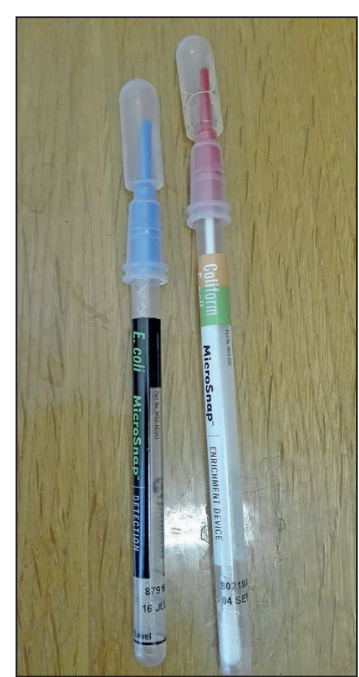

2. ábra. Escherichia coli + Coliform dúsító, és méröcső

1. táblázat. Élelmiszerek mikrobiológiai megfelelőségének vizsgálata ATP méréssel hús- és húskészítmények esetében

\begin{tabular}{|c|l|c|c|c|}
\hline Fsz. & \multicolumn{1}{|c|}{ Termék megnevezése } & $\begin{array}{c}\text { Besorolás a 4/1998. } \\
\text { EüM sz. rendelet } \\
\text { alapján }\end{array}$ & $\begin{array}{c}\text { Vizsgálat/határérték } \\
\text { határérték } \\
\text { RLU }\end{array}$ & $\begin{array}{c}<100 \\
<35\end{array}$ \\
\hline 1. & $\begin{array}{l}\text { Előhűtött egész sertéskaraj } \\
\text { (csont nélküli) }\end{array}$ & II./1.1. & $\begin{array}{c}\text { Mikrobaszám }\left(M=10^{7}\right) \\
\text { E. coli }\left(M=5 \times 10^{2}\right)\end{array}$ & $\begin{array}{c}\text { Mikrobaszám }\left(M=10^{7}\right) \\
\text { E. coli }\left(M=5 \times 10^{2}\right)\end{array}$ \\
\hline 2. & $\begin{array}{l}\text { Előhűtött sertéslapocka } \\
\text { (csonttal) }\end{array}$ & II./1.1. & E. coli $\left(M=5 \times 10^{3}\right)$ & $<35$ \\
\hline 3. & Sertésvirsli juhbélben & II./1.3. & E. coli $\left(M=5 \times 10^{3}\right)$ & $<180$ \\
\hline 4. & Sertéspárizsi & II./1.3. & E. coli $\left(M=5 \times 10^{3}\right)$ & $<180$ \\
\hline 5. & Nyári turista felvágott & II./1.3. & E. coli $\left(M=5 \times 10^{3}\right)$ & $<180$ \\
\hline 6. & Olasz felvágott & II./1.3. & E. coli $\left(M=5 \times 10^{3}\right)$ & $<180$ \\
\hline 7. & Lángolt kolbász & & & \\
\hline
\end{tabular}


mint 8 óra alatt képesek kimutatni kóliformokat és Escherichia coli baktériumokat. A teszt egy táptalajt tartalmazó dúsító mintavevő tamponból áll, amely a baktérium által termelt biomarkereket (mérhető biológiai jelzőanyag) egy hordozható luminométerrel képes mérni. Első lépésként a mintát inkubáljuk a táptalajban, hogy a baktériumok száma növekedjen. Ahogy nő a baktériumok száma, úgy egyre több enzim (béta-galaktozidáz és béta-glükoronidáz) termelődik, amelyek szükségesek a biolumineszcens vizsgálathoz. A dúsított mintaoldat egy részét áttesszük a mérőeszközbe, aktiváljuk, majd előírt ideig tovább inkubáljuk. Ez idő alatt a specifikus szubsztrát reakcióba lép az enzimekkel és fényt bocsát ki, ami a luminométerrel mérhető. $A z$ eredmények relatív fény egység (RLU - Relative Light Unit) mértékegységben jelennek meg.

A tesztek használhatók felületek, termékminták, víz és más szűrhető folyadékok vizsgálatához.

\section{MICROSNAP TOTAL - ÖSSZCSÍRASZÁM KIMUTATÁSÁRA}

A MicroSnap EB (Enterobacteriaceae) egy biolumineszcencián alapuló gyors eljárás az összes baktériumszám kimutatására és megszámlálására; egy mintából 7 óra alatt ad eredményt. Hasonló elven müködik, mint a MicroSnap Coliform és Escherichia coli baktériumok kimutatására használatos eszköz. A MicroSnap Total egy szabadalmaztatott táptalajt tartalmazó dúsító mintavevő tamponból (Enrichment Swab Device) és a bioluminogén reagenst tartalmazó mérőeszközből (Detection Device) áll, amely a baktérium által termelt biomarkereket hordozható luminométerrel képes mérni. A kétlépéses eljárás, a baktériumok növekedését megkönnyítendő egy rövid inkubációs szakasszal indul, majd a második lépést a megszámlálásuk jelenti. Az inkubálási idő alatt a táptalajban növekszik a baktériumok száma. Minél nagyobb a baktériumok száma a mintában, annál magasabb a biomarker koncentráció és annál magasabb a kibocsátott fény. A dúsított mintaoldat egy részét áttesszük a mérőeszközbe (Detection Device), aktiváljuk, összekeverjük és megmérjük a luminométerrel. A fénykibocsátás egyenesen arányos a jelen lévő baktériumok koncentrációjával. Az eredmény relatív fényegység (RLU) értékben jelenik meg.

A MicroSnap Total felületek, termékminták, víz és más szűrhető folyadékok vizsgálatához egyaránt felhasználható.

Felületi mintavétel javasolt:

- tőkehúsok (sertéskaraj, lapocka);

- baromfi termékek (csirkemell, csirkecomb, csirke farhát);

- zöldség, gyümölcs (uborka, paradicsom, burgonya);
- gyorsfagyasztott termékek (szilvás derelye, nudli, csirkezúza) esetében.

Mérést igénylő termékminta vizsgálata javasolt:

- feldolgozott hústermék (virsli, párizsi, felvágott, kolbász);

- tejtermékek (túrórúd, tehéntúró, joghurt, kefír, krémtúró, sajt) baromfi és baromfitermék (baromfi kenőmájas, aszpikos pulykacomb, pulykasonka);

- gyorsfagyasztott termékek (gyorsfagyasztott zöldségek, keverékek);

- cukrászati termékek (sütemények, gesztenyepüré) esetében.

A mikrobiológiai gyorstesztek tárolása $2-8{ }^{\circ} \mathrm{C}$ között történik, minőségmegőrzési ideje 12 hónap. A MicroSnap eszközöket kidobás előtt fertőtleníteni szükséges autoklávban, vagy áztatással 20\%-os fertőtlenítő oldatban 1 órán keresztül. Csak ez után lehet a teszteket kidobni a kommunális hulladék közé.

\section{BERENDEZÉSEK/MÉRÖESZKÖZÖK}

\section{LUMINOMÉTER}

Az ATP tesztek kiértékeléséhez használatos. A luminométeren beállíthatók a vizsgált termékféleségek, beprogramozhatók a hozzájuk tartozó küszöbértékek, illetve a felhasználó személy neve. A bekapcsolást követően a műszer 15 másodpercig önkalibrálást végez, akklimatizálódik a környezeti hőmérséklethez és páratartalomhoz.

Bizonyos termékek nagy mennyiségben gátolják a biolumineszcenciás reakciót. A láthatóan szennyezett felületekről vett minta gátolhatja a reakciót, ezért ezeket a felületeket célszerű elkerülni. Miután megtörtént a mintavéte-

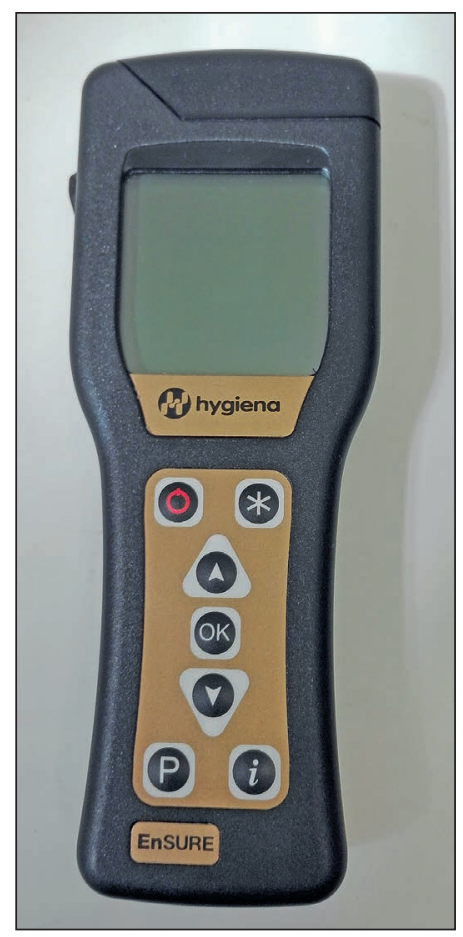

4. ábra. Luminométer
3. ábra. Felületi mintavétel (bal oldal), mérést igénylő mintavétel (jobb oldal)

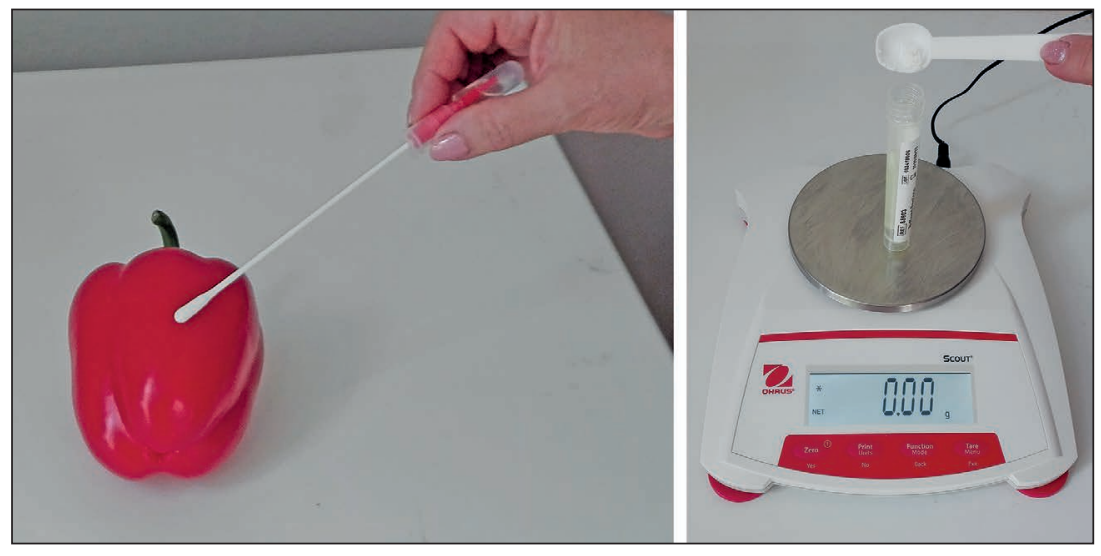

lezés, a mintavevő tamponokat legfeljebb 4 órán át lehet tárolni az aktiválás előtt. Aktiválást követően 60 másodperc áll rendelkezésre az eredmény leolvasására. A vizsgálat eredménye 15 másodpercen belül megjelenik/leolvasható.

A luminométer memóriájában (2000 teszt elmentésére alkalmas) tárolt vizsgálati eredmények a SureTrend adatelemző szoftver használatával számítógépre tölthetők. A szoftver a luminométerhez mellékelt CD-n található. 


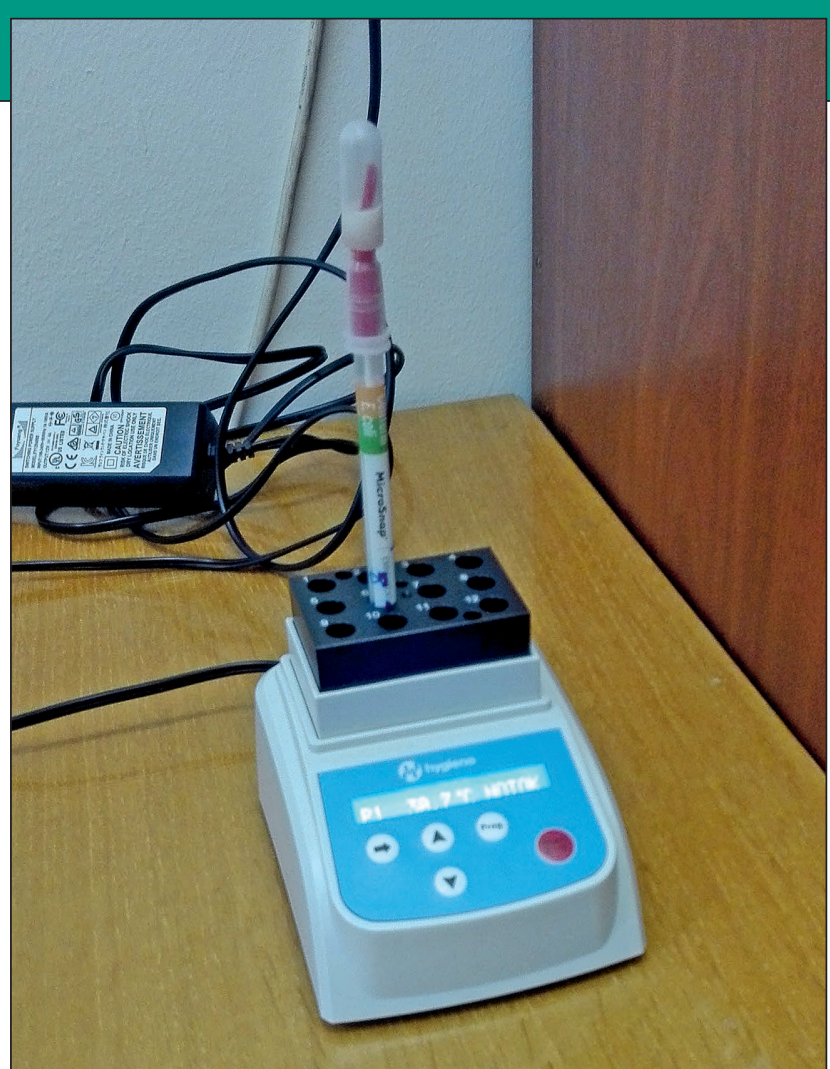

5. ábra. Mini inkubátor

\section{MINI INKUBÁTOR}

Az inkubátor a baktériumok növekedéséhez szükséges hőmérsékletet biztosítja a megfelelő ideig. 6-12 teszthez használható, digitális kijelzővel rendelkezik, kevesebb, mint 15 perc alatt felfüt a maximális hőmérsékletre, beépített időzítője van. Az inkubátorhoz adapter is tartozik gépkocsiban történő használathoz, amely - a gyors eredmények elérése érdekében - lehetővé teszi a menet közbeni inkubálást.

\section{HORDOZHATÓ MÉRLEG}

Az élelmiszer termékek beméréséhez használható. Méréstartománya 220 g, adapterről vagy elemekről müködik.

ESCHERICHIA COLI + COLIFORM DÚSITÓ, ÉS MÉRÖCSÖVEK, ÖSSZCSÍRADÚSITÓ ÉS MÉRŐCSÖVEK, ADAPTER (INVERTER) GÉPKOCSIBAN TÖRTÉNÖ HASZNÁLATHOZ

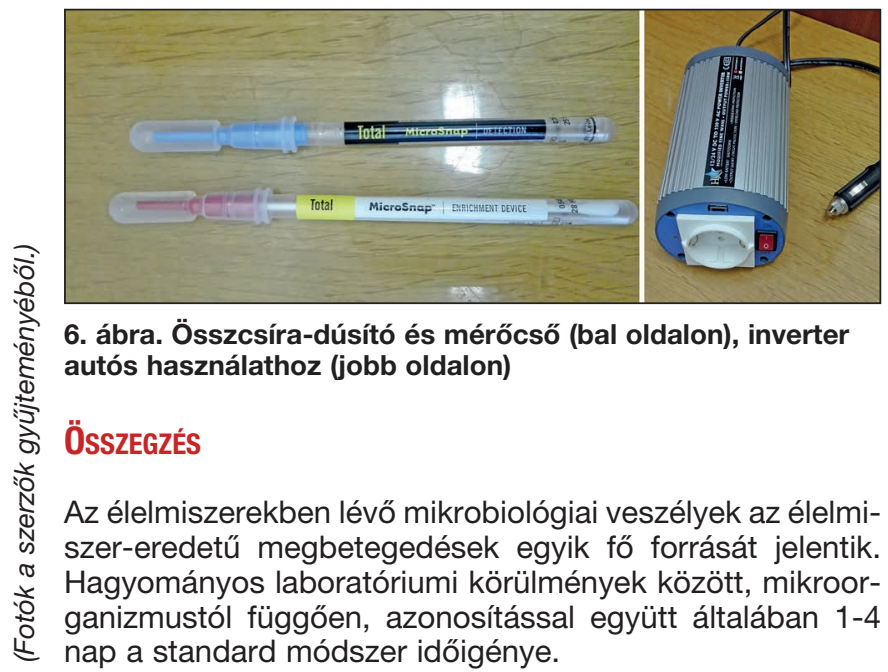

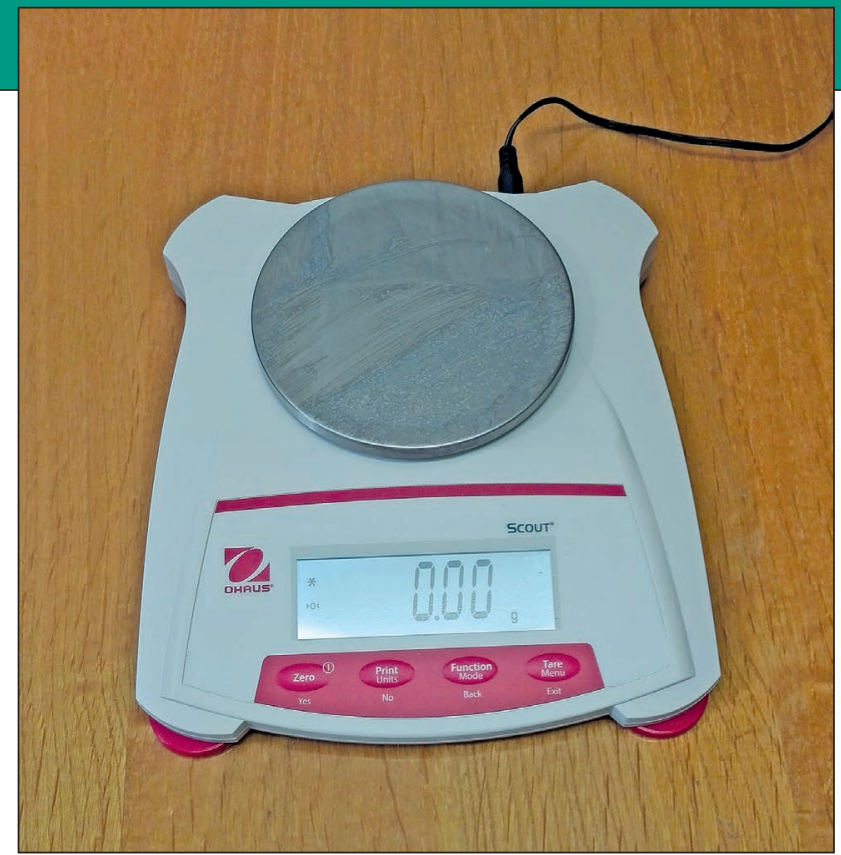

7. ábra. Hordozható mérleg

A meglehetősen hosszú vizsgálati idő miatt igény mutatkozott arra, hogy a szakemberek a mikrobák kimutatására szolgáló hagyományos élősejtszám-meghatározási módszereket gyorsabb vizsgálati eljárásokkal váltsák fel.

A mikrobiológiai gyorstesztek bevezetése a honvédelmi szervezeteknél gyorsabb minőség-ellenőrzésre ad lehetőséget az élelmiszerek esetében. Az új müszerekkel és eszközökkel (pl. az inkubátor autóban való működtetésével) az elvégzett vizsgálatokról még aznap eredmény közölhető. Ez lehetővé teszi, hogy a bevizsgált élelmiszerekről rövid időn belül kijelenthető legyen, hogy - a bevizsgált paramétereket tekintve - biztonsággal elfogyaszthatók.

A korszerü, a Magyar Honvédségben is használatos mérőeszközökkel a kimutatható patogén baktériumok köre bővíthető, illetve akár allergén agyagok jelenléte is vizsgálható.

\section{IRODALOMJEGYZÉK}

[1] Blood, Ruth M., and G.D.W. Curtis. "Chapter 10 Media for 'total' Enterobacteriaceae, Coliforms and Escherichia Coli." Progress in Industrial Microbiology (1995): 163-185. https://doi.org/10.1016/s00796352(05)80012-8;

[2] Deák Tibor, Kiskó Gabriella, Maráz Anna, Mohácsiné Farkas Csilla. Élelmiszer-mikrobiológia, Bp.: Mezőgazda Kiadó, 2006.;

[3] Dr. Belák Ágnes, Dr. Kiskó Gabriella, Dr. Kovács Mónika, Dr. Maráz Anna, Mohácsiné dr. Farkas Csilla, Dr. Pomázi Andrea: Gyors és molekuláris biológiai módszerek alkalmazása élelmiszerek mikrobiológiai vizsgálatára - Gyakorlati kézikönyv, Nemzeti Tankönyvkiadó, 2011.;

[4] Dr. Erdősi Orsolya: Gyors mikrobiológiai módszerek fejlesztése és alkalmazása élelmiszer- és környezet-higiéniai vizsgálatokban, PhD értekezés, 2014 Letöltve: 2019.07.17. http://www.huveta.hu/bitstream/ handle/10832/1130/PhD_Erdosi_Orsolya.pdf;

[5] Stannard C. J. „ATP Estimation.” in Rapid Methods in Food Microbiology, ed. Adams, M. R. and Hope, Elsevier, 1989.;

[6] 4/1998. (XI. 11.) EüM rendelet az élelmiszerekben előforduló mikrobiológiai szennyeződések megengedhető mértékéröl;

[7] 2073/2005 (11.15) EK rendelet az élelmiszerek mikrobiológiai kritériumairól. 